\title{
ANIMALS AS SYMBOLS OF HUMAN POSITIVE AND NEGATIVE TRAITS ON JAVANESE EXPRESSIONS
}

\author{
Tri Wahyu Setiawan Prasetyoningsih ${ }^{1 *}$; Dyah Raina Purwaningsih ${ }^{2}$; Nadia Gitya Yulianita $^{3}$ \\ 1,2.3Jurusan Bahasa dan Sastra Inggris, Fakultas Ilmu Budaya, Universitas Jenderal Soedirman \\ Jl. dr. Soeparno Utara No. 1, Grendeng, Purwokerto 53122, Indonesia \\ 1tri.wahyu@unsoed.ac.id; 22dyah.purwaningsih@unsoed.ac.id; ${ }^{3}$ nadiagityay@unsoed.ac.id
}

Received: $30^{\text {th }}$ October 2020/Revised: $17^{\text {th }}$ January 2021/Accepted: $18^{\text {th }}$ January 2021
How to Cite: Prasetyoningsih, T. W. S., Purwaningsih, D. R., \& Yulianita, N. G. (2020). Animals as symbols of human positive and negative traits on Javanese expressions. Lingua Cultura, 14(2), 255-260.
https://doi.org/10.21512/lc.v14i2.6772

\begin{abstract}
The research aimed to analyze the metaphor of animals'names in Javanese expressions as representing power and authority in its positive and negative sides. The ancient land of Java was ruled by kings. This situation indicated that ancient Javanese were closely related to kingdoms and regulations that were strict rules of politeness rules or authoritarian. It created a situation where direct criticisms, suggestions, and warnings were conveyed to those who had power, which might cause the problem to the conveyor. Thus, people preferred to express their opinion in the metaphorical form to preserve the Javanese manners. Since Javanese people also lived as farmers and hunters, they could identify the nature of various animals' characters. They began to compare some animals'nature characters to describe human characters or behaviors in the forms of metaphor known as Javanese expressions. The methods applied were a descriptive qualitative by choosing the data that contained animal names, classifying them, analyzing the meanings of the expressions, and providing results of the analysis. These metaphorical forms are hitherto known as proverbs and are make used them as philosophy of life. They also used proverbs. The data were taken from "Seri Kajian Sastra Klasik 100 Paribasan Jawa Simpul-Simpul Kearifan Lokal Budaya Jawa" by Bambang Husen Al Marie in 2018. There are 26 expressions using animal names found in this dictionary. Macan, gajah, and asu are the three animals that are mostly used as a metaphor to describe human characters within a sovereignty. Heuristic and hermeneutic approaches are applied to analyze the data and to find out the real meaning of the classified data.
\end{abstract}

Keywords: animal symbols, human traits, Javanese expressions, Javanese proverbs

\section{INTRODUCTION}

Indonesia consists of various tribes and languages that have many proverbs spreading in areas of this country. According to the Great Dictionary of the Indonesian Language (KBBI), the proverb is a short and concise expression containing comparisons, parables, advice, and life rules. Thus, proverbs are rich in the philosophy of life, such as spirit, wisdom, as well as warning to be self-aware and careful at all times in living this life. Furthermore, it is believed that proverbs are orally transferred by the ancestors as a reminder to be vigilant so that nothing terrible happens.

As one of the tribes in Indonesia, the Javanese holds many proverbs used as the foundation of their way of life. This makes Javanese life is reflected in their richness of proverbs as local wisdom. The proverb also becomes a way for Javanese people to express their perspective about a case opinion. The understanding of these expressions indirectly shapes them to strive in order to always be in harmony with the norms and values of the society that have become an agreement.

Moreover, the lands of Java were ruled by kings of both large and small kingdoms. It required the Javanese to respect their authority by highly upholding manners and politeness and beware more aware of delivering an opinion known as unggah ungguh. When they wanted to convey admiration or even criticized the kings, they chose to deliver it through proverbs not to be considered impolite people. Javanese value system did not provide many opportunities for open individual expression. However, the use of idioms or Javanesse expressions as a way of expressing an 
opinion is applied nowadays by Javanese women on to political conversation (Lestari et al., 2019).

Even though proverbs can be considered an effective method to reveal a broad meaning, this pragmatic way sometimes makes it difficult to grasp a proverb's true meaning. It happens because Javanese expressions have many figurative meanings. Most of them are in the form of comparison, analogy, and certain vocabularies selected as symbols of the human traits and behavior things they want to express. Therefore, in-depth and comprehensive analysis is needed to gain the actual hidden meaning of a proverb.

The proverbs observed in the research are those which contain animals' names elements. Most of the ancient Javanese worked as farmers and hunters. It indicates that Javanese were also close to the life of animals. This condition caused them to figure out nature, animals' activities, human activities, and their characteristics result in Javanese proverbs recognized today. The Javanese then compared the animals' nature characters and human traits to relate them to their context. If they wanted to describe human characters, behavior, or condition, they would use animals with similar characteristics to these things as symbols. The way of delivering these proverbs belongs to metaphor.

This indirect way to express ideas and thoughts is done by comparing two things or more without using comparison expressions, such as 'like', 'as if', 'as', and so on. Metaphors can be understood by comparing two domains, namely target domain and source domain. The first refers to a concept described through metaphor, while the second refers to a concept used to construct a metaphor. People associate a concept with other concepts using language by applying associate strategies. The associate strategies mean human uses his semantic memories by associating characteristics of one entity with another entity. Rahardian and Nirmala (2018) have claimed that psycholinguistics' theory in understanding metaphor means that meaning behind a metaphor can be understood by showing analogy, comparing, and transferring the perceived characters.

Data in the research are the proverbs listed in Seri Kajian Sastra Klasik 100 Paribasan Jawa Simpul-Simpul Kearifan Lokal Budaya Jawa by Bambang Husen Al Marie in 2018. There are 100 Javanese proverbs in this series, and 26 of them use animal names as the entities, such as Nguthik-uthik macan dhedhe. The word macan or (tiger) symbolizes power, greatness, and leadership. Nguthik-uthik describes an activity carried out intending to disturb a peaceful situation. Nguthik-uthik macan dhedhe can be inferred as an action of disturbing people who have more power (Al Marie, 2018). Besides macan that symbolizes supremacy, there is an animal that ancient Javanese considered as a dirty and greedy animal, namely asu (dog). Asu will be raised only if it is used as a hunting animal because of its nature. Nevertheless, asu in Javanese proverbs is used to describe negative characters or things. Asu arebut balung is an example of a proverb that implies negative meaning. Balung is a bone with no more flesh attached to it. The use of the word balung denotes an unimportant thing. Hence, this proverb describes people who are fighting over trifles (Al Marie, 2018).

The research aims to analyze the metaphor of the animals' names in Javanese expressions that symbolizes good and bad matters within leadership and authority. The consequences of leadership, such as criticisms, advice as well as warning, are reflected in Javanese expression in the form of metaphor.

The studies on metaphors have been conducted by several researchers, such as Diputra (2017), who discusses the meaning of color connotations around Balinese, such as white, black, green, orange, yellow, purple, and red. The data sources are speeches that contain colors, both the use of color connotation and the use of special names of colors applied by Balinese speakers. The research in of metaphor of in color is also conducted by Fadhilah, Rais, and Purnanto (2019). They describe the Madurese color lexicon with plant attributes. In contrast, Umam and Nirmala (2020) have focused their research on color metaphors in English and Indonesian song lyrics. Another research on metaphor can be found in Rahardian and Nirmala's (2018) research that explores the metaphor on Javanese emotion on the force. Also, Hartanto (2018) has observed the cognitive metaphor in speech acts of Islamic teachings in Surakarta. Similar studies on Javanese expression have been performed by other researchers. Abdullah (2016) has examined the background of Javanese proverbs used in the Javanese community in the ex-residency of Surakarta and explained the cultural meaning of these proverbs.

In addition, the research on the lexicon classification of animals by using a cognitive semantic approach is conducted by Nugraha (2019), and the criticism in Javanese expression has been analyzed by Wahyuni (2020). She presents her research results through cognitive semantic research, which aims to describe these expressions and their philosophical meaning of these expressions. She states that there are 24 Javanese expressions, which contain critical meaning. This expression indicates personification figures, which are the conceptualizations of human characters. In the same year, the translation of Javanese culture expression in a novel is conducted by Nugrahani et al. (2019). Mansyur and Suherman (2020) have explored information about the function of proverbs used as educational media. Meanwhile, this research is arranged to discuss Javanese proverbs and expressions, yet the focus is on analyzing the metaphor of the animals' names, which become the symbol of human positive and negative behaviors.

\section{METHODS}

The method applied in the research is descriptive qualitative since it discusses the animals' name, which is used as a symbol of power and authority in Javanese proverbs. The research data are the proverbs taken from Seri Kajian Sastra Klasik 100 Paribasan 
Jawa Simpul-Simpul Kearifan Lokal Budaya Jawa by Bambang Husen Al Marie in 2018. Furthermore, the object is the process of how the animals' names could be interpreted as a representation of two opposite sides as the consequence of power.

Since both positive and negative sides of power in these proverbs are expressed through metaphors, library research is also done to observe and analyze the data. Only the proverbs containing animals' names representing human characters within supremacy become the main data in the research. They were are macan (tiger), gajah (elephant), and asu (dog). After exploring some literature, it can be concluded that these three animals represent circumstances that existed in leadership.

The categorized data are then analyzed by using two-step of semiotics analysis. These two steps are heuristic and hermeneutic. In the heuristic reading step, the data would be translated literally to obtain an exact actual meaning of a word using Kamus Bausastra Jawa by Purwadarminta and Javanese and English Dictionary Horne. These two dictionaries are used as the main sources to elaborate the literal meanings of each word. The data in the form of derivative verbs are also analyzed morphologically to get the literal meaning and function in the proverbs.

Meanwhile, in the hermeneutic reading step, the data are considered symbols that must be interpreted to find their real hidden meaning (Muganga, 2016). This stage is done after the heuristic reading stage (Inayati \& Nuryatin, 2016). In the research, the hermeneutics reading approach should be applied since Javanese proverbs contain many figurative meanings. Besides, careful and in-depth reading must also be carried out in analyzing these Javanese proverbs. Exploring and comprehending the meaning contained could be explored and understood comprehensively and precisely.

\section{RESULTS AND DISCUSSIONS}

The result of the research contains the outcome. In contrast, the discussion contains the analysis process of the objects to arrive at a conclusion. Based on the analysis, there are 26 Javanese proverbs that contain animal's names elements as its the entities in "Seri Kajian Sastra Klasik 100 Paribasan Jawa SimpulSimpul Kearifan Lokal Budaya Jawa". They are classified into livestock, pet, prey, and the wild. The proverbs classification used 16 animals, namely welut (eel), iwak (fish), bebek (duck), manuk (bird), emprit (a kind of bird), udhet (eel child), kebo (buffalo), asu (dog), gudel (bull), kucing (cat), gajah (elephant), kidang (deer), cindhil (baby rat), ula (snake), beruk (ape), and macan (lion). Table 1 describes the findings of this research.

After observing the data comprehensively, macan, gajah, and asu are the most common animals that appeared in these proverbs dictionary. Macan is mentioned four times, gajah is mentioned three times, and asu is mentioned five times. Javanese associates gajah and macan as symbols of leadership, strength, power, and authority. Meanwhile, asu is recognized as a symbol for a negative thing or person. This symbolization emerges from its physical appearances and characters' natures.

The data are analyzed heuristically and hermeneutically. Heuristic reading means that the data will be analyzed literally based on how the word is built and the actual meaning of its base form. By applying hermeneutic reading, the meaning of a proverb based on heuristics reading can be interpreted and analyzed. This interpretation is made by relating the symbols with their contexts.

The first stage of interpreting these Javanese expressions is heuristic reading. The structure of the expressions is discussed by Sipahutar and Arianto (2019). Herawati, Rustono, and Poedjosoedarmo

Table 1 Research Findings

\begin{tabular}{|c|c|c|}
\hline Animals & Symbolization & Expressions \\
\hline \multirow[t]{4}{*}{ Macan (tiger) } & leadership, strength, power and authority & 1. Nguthik-uthik macan dhedhe \\
\hline & & 2. macan guguh \\
\hline & & 3. kekudhung walulang macan \\
\hline & & 4. singidan пети macan \\
\hline \multirow[t]{3}{*}{ Gajah (elephant) } & leadership, strength, power and authority & 1. cindhil ngadu gajah \\
\hline & & 2. anggajah êlar \\
\hline & & 3. gajah ngidak rapah \\
\hline \multirow[t]{4}{*}{$A s u(\operatorname{dog})$} & Negative thing or person & 1. Rindhik asu ginitik \\
\hline & & 2. Asu gedhe menang \\
\hline & & 3. Asu arebut balung \\
\hline & & 4. Asu belang kalung wang \\
\hline
\end{tabular}


(2016) have stated that This heuristic reading consists of two kinds of derivation: transposition and nontransposition. Transposition derivation means that affixes change the word class. In contrast, nontransposition derivation means that the affixes added do not change the word class. She also describes the verb formation found in the Javanese language, which is used to analyze the heuristic reading in the research. Based on the heuristic analysis, there are six active verbs derived from three kinds of prefixes. These three prefixes are a nasal sound $\left\{N_{-}\right\}$that meets allomorph - ang, a nasal sound $\{\mathrm{N}-\}$ that meets base form initiated with a consonant, prefix $-a$, and a suffix $-a n$. The first is found in the verbs nguthik-uthik, ngadu, anggajah, and ngidak. The second is found in the verb nemu, the third is found in the word arebut, and the last one is found in the word singidan. Besides, there is a passive verb that is derived from the prefix $k e$ - that is kekudhung.

The animals' elements names found in Seri Kajian Sastra Klasik 100 Paribasan Jawa SimpulSimpul Kearifan Lokal Budaya Jawa denote the symbols related to the power of authority. Macan, gajah, and asu are the animal's recognized elements as the symbols that represent a power, of which its good sides and bad sides are described metaphorically. People, in this case, Javanese, considered macan or tiger as a strong and fierce animal. These strong characters' natures of a tiger become the reasons why a tiger is used as a symbol of greatness. When a person is compared to this entity, it means that he/ she is someone who is dominant and has strong power and or authority. Macan can also be a personification of a leader. The word 'macan' are found four times in this research. They are Nguthik-uthik macan dhedhe, macan guguh, kekudhung walulang macan, and singidan nemu macan.

The first proverb about macan is nguthik-uthik macan dhedhe. This proverb contains three words that are nguthik-uthik, macan, and dhedhe. Nguthik-uthik consists of a nasal sound $\{N-\}$ and an allomorph -ang. This formation becomes the prefix of uthik-uthik. Uthik-uthik is a verb that means a repeatedly touch upon something with fingers. It implies an annoying or a bothering behavior or to interfere purposely. While dhedhe is also a verb that is relevant to sunbathing. It is a relaxing activity. Literally, macan dhedhe means a lazy tiger that does not want to be disturbed. As macan is a metaphor of a leader, the implication of nguthik-uthik macan dhedhe is disturbing the one who is currently in power, and he/she is in the state of no noise. Someone who, intentionally or not, disturbed a leader can put himself in big trouble or at least unpleasant circumstances.

Literally, macan guguh means an old tiger that does not have teeth anymore. The word guguh means toothless. As a matter of fact, teeth are the symbol of youth and strength. Macan, even though it has been old, is still a feared animal. Thus, macan guguh can be interpreted as someone who is no longer in power, but he is still respected and influential. Many people still believe in his/her words, so his/her opinion is of a case is still a matter (Al Marie, 2018).

Kekudhung consists of prefix -ke and verb kudhung. Prefix -ke forms a derivative verb or passive verb, which implies doing something accidentally. Kudhung means something that is used to cover the head. Poerwadarminto provides cloth and caping (hat of farmers made from woven bamboo of broad conical shape) as examples. In addition, the word Walulang or lulang means leather. Thus, considering that macan indicates a wild animal that symbolizes control, hermeneutically, it can be concluded that the proverb 'kekudhung walulang macan', which means someone who takes advantage behind the power of others. He/ she uses people in power for his/her personal interests.

Another proverb that contains macan as its element is singidan nети macan. Singidan is formed from the verb singid, and it gets suffix -an. The word singid means to hide or to conceal something. The suffix -an forms a derivative, which means doing a thing with a certain purpose. The word nети comes from nasal $\left\{N_{-}\right\}$and a base form verb, temu. Literally, the word temu in Javanese could mean find or see. In this proverb, macan is not a symbol of power, but it is a symbol of danger. Hence, the meaning of the proverb singidan nети macan can be interpreted as someone who tries to avoid the bad thing; instead, he/she meets dangerous thing.

There are three proverbs contained gajah as the entity compares to human. They are cindhil ngadu gajah, anggajah êlar, and gajah ngidak rapah. The main object in these proverbs is gajah (elephant). This entity is a big and strong animal, and it represents power and greatness. Hence, human compared to gajah is the one who is in power and is considered as a leader. This proverb is made up of three words that are cindhil, ngadu, and gajah. Cindhil is a child or baby rat. It is small and red. Thus, cindhil is a symbol of weakness and helplessness. The morphological process of $n g a d u$ can be described as a nasal sound $\{N-\}$ which meets allomorph - ang and form an implication of doing something in purpose. This prefix then forms an active verb $a d u$. $A d u$ means to bring an entity into a confrontation. It can be inferred that the word ngadu means to confront intentionally. Therefore, the proverb cindhil ngadu gajah embraces a meaning of a weak person who is able to bring strong or powerful people into a conflict. He/she can use this conflicted situation for his/her personal intention.

The word anggajah is also structured morphologically from a nasal sound $\left\{N_{-}\right\}$and an allomorph -ang that meets the noun gajah or elephant. This process changes the noun (gajah) into an active verb (anggajah). Anggajah implies resembling an elephant, which are is big and powerful. The word êlar means part of the body used to fly, and it symbolizes wish and desire. By combining these two entities, anggajah elar describes a person who is in a high position, rich, and all his/her desires are fulfilled or even excessive. $\mathrm{He} / \mathrm{sh}$ is considered as someone who is very lucky in his/her life. 
Like the two previous morphological formations of active verbs on proverbs, ngidak is also structured by the combination of nasal sound $\{N-\}$ and allomorph -ang. This prefix then assimilates with the verb idak and form an active verb, ngidak. The basic verb idak means to step on a thing. Besides, literally, rapah means leaves and twigs scattered on the ground. Rapah in this proverb represents regulation or rules. There is a folklore that makes the word rapah. A long time ago, hunters used various methods to catch their prey, such as tiger, wild boar, and other animals. One of the methods used was setting up a trap by digging large holes and covering them with dry twigs and leaves known as rapah. The targeted animals are expected to step on the leaves and finally become trapped. Supposedly, if a royal joined in a hunt, he would involve many soldiers on horses or elephants. One day, an elephant that was being ridden fell into a trap that had been set. This event was later referred to as gajah ngidak rapah. Since many traps had been set, Thean elephant rider should have known that he could not step on the trap because he set the trap. If an elephant rider and his mounts fell into one of the set traps, it is described as gajah midak rapah.

In this proverb, gajah, as a large animal, is a symbol of a leader. A leader, as the one who makes regulations and understands the contents, should never violate them. Hence, the proverb gajah ngidak rapah is a satire to someone (it usually refers to a leader) who broke the rules that he/she has been made.

Most Javanese proverbs that use the word asu as one of its entities contain negative connotations. It happens because many asu of dogs do not possess positive characters as pets or bloodhounds. There are dogs that bite and eat dirty food. These lead to the word asu as representing negative characters, such as greedy, aggressive, stubborn, and hostile. Besides, the word asu is also widely used as a swear word. Javanese proverbs, which contain asu are describing humans who have these negative characters. Some of the Javanese proverbs are Rindhik asu ginitik, Asu gedhe menang kerahe, Asu arebut balung, and Asu belang kalung wang. This proverb has a base form of a verb and a derivational verb. The word rindhik, as a base form of the verb, implies slow moves or cowish. Meanwhile, the derivational verb ginitik is structured from a noun gitik, which means small stick or small rattan, and an infix -in, which forms a passive verb. Thus, the word ginitik means being beaten with a small stick or small rattan. Hence, the proverb rindhik asu ginitik describes a person who has a quick response to a command from a leader, even faster than a dog being hit. This proverb sometimes becomes a satire for people who have this kind of response. However, the intention is apple polishing so that his personal interests are fulfilled.

Literally, gedhe means big, menang means winning a fight, and kerah means to fight between animals, likes biting or chewing each other. The word kerah is a verb added by the suffix $-e$, which changes this verb class into a noun. It can be concluded that asu gedhe menang kerahe describes people who have a high position in society will always be the winner in every conflict, both in serious and trivial matters. He/ she is able to make use of his/her power to justify all means to be dominant. Even he/she does the wrong thing; he could get away with it.

The word arebut is structured from a prefix $-a$, and a verb rebut. Prefix $-a$ forms of a derivative verb or active verb. Meanwhile, the verb rebut describes a situation of doing something in one-self-interest without regard for others. The noun balung means bone. Since bone is a part of the body with no flesh anymore, balung is usually used to describe something that is no longer useful. Hence, asu arebut balung describes a situation where two people are fighting over insignificant matters.

Belang is the scars found in the outermost part of a body, both on humans and animals. It is usually found on the skin. Belang is also intended to describe negative sights. Kalung means a necklace or something that is used around the neck, and wang means money. Asu belang is usually considered a disgusting and unwelcome animal. Here, asu belang describes an uneducated and despicable person. At the same time, kalung wang symbolizes abundant wealth. Literally, this proverb describes a disgusting dog with money wrapped in its neck. It means that asu belang kalung wang represents a person with a low social status that embraces much wealth and possession. It is a peculiarity for few people with such status (Al Marie, 2018). Hence, some people use this expression as satire. They think that it is impossible for a person of low social status to be rich. The wealth will fall under suspicion as wealth is obtained by stealing or other improper ways.

\section{CONCLUSIONS}

A metaphorical analysis of these Javanese expressions enables people to have a better understanding of their hidden meaning. These expressions are used to describe human behaviors and situations where one party is more dominant than the other. There are 26 Javanese expressions that contain animal elements as entities that are used to describe human characters. Macan, gajah, and asu are the three animals that are mostly used in the expression. Macan and gajah are the symbols of greatness and strength. Most of the expressions using these two animals describe positive things. Meanwhile, asu is used as a symbol of bad human characters. Its bad characters are considered suitable to represent the bad and greedy human.

\section{REFERENCES}

Abdullah, W. (2016). The local wisdom summarized in the Javanese proverbs: A case study of the Javanese community in ex-residency of Surakarta 
(An ethnolinguistic study). Advanced Science Letters, 22(12), 4519-4523. https://doi.org/10.1166/ asl.2016.8208.

Al Marie, B. H. (2018). Seri kajian sastra klasik 100 paribasan Jawa simpul-simpul kearifan lokal budaya Jawa. Retrieved from https://docplayer. info/185544346-Seri-kajian-sastra-klasik-100paribasan-jawa-simpul-simpul-kearifan-lokalbudaya-jawa-disajikan-dalam-bahasa-indonesiaoleh.html.

Diputra, G. D. R. (2017). Konotasi warna pada masyarakat Bali. Linguistika, 24(47), 203-220.

Fadhilah, N., Rais, W. A., \& Purnanto, D. (2019). Metaphor analysis on color lexicon with plant attributes in Madurese language. Lingua Cultura, 13(3), 191199. https://doi.org/10.21512/lc.v13i3.5769.

Hartanto, W. (2018). Metafora kognitif tuturan penceramah dalam pengajian di wilayah Surakarta. Kandai, 14(2), 181-196. https://doi.org/10.26499/jk.v14i2.643.

Herawati, N., Rustono, M. H., \& Poedjosoedarmo, S. (2016). Prefixes of denominal verb formation in javanese language. Journal of Education and Social Sciences, 5(2), 151-156.

Inayati, T., \& Nuryatin, A. (2016). Simbol dan makna pada puisi menolak korupsi karya penyair Indonesia. Seloka: Jurnal Pendidikan Bahasa Dan Sastra Indonesia, 5(2), 163-171. https://doi.org/10.15294/ seloka.v5i2.13078.

Lestari, P., Djatmika., Sumarlam, S., \& Purnanto, D. (2019). Javanese women's political discourse in response to the 2019 Indonesian general election. Journal of Social Studies Education Research, 10(3), 193-201.
Mansyur, F. A., \& Suherman, L. A. (2020). The function of proverbs as educational media: Anthropological linguistics on wolio proverbs. ELS Journal on Interdisciplinary Studies in Humanities, 3(2), 271286. https://doi.org/10.34050/els-jish.v3i2.10505.

Muganga, L. (2016). The importance of hermeneutic theory in understanding and appreciating interpretive inquiry as a methodology. Journal of Social Research and Policy, 6(1), 65-88.

Nugraha, D. (2019). The lexicon of animal classification in Javanese: A cognitive semantic approach. International Journal of Humanity Studies, 2(2), 186-195. https://doi.org/10.24071/ijhs.2019.020208.

Nugrahani, D., Nababan, M., Santosa, R., \& Djatmika, D. (2019). Translating Javanese culture expressions in a novel: Techniques and quality. Journal of Social Studies Education Research, 10(2), 323-343.

Rahardian, E., \& Nirmala, D. (2018). The force scheme in Javanese emotion metaphors. PAROLE: Journal of Linguistics and Education, 8(1), 12-18. https://doi. org/10.14710/parole.v8i1.12-18.

Sipahutar, R., \& Arianto, T. (2019). An analysis of semiotic riffaterre in Walt Whitman selected poem. Journal BASIS, 6(2), 237-248. https://doi.org/10.33884/ basisupb.v6i2.1428.

Umam, K., \& Nirmala, D. (2020). Color metaphor in English and Indonesian song lyrics. RETORIKA: Jurnal Bahasa, Sastra, dan Pengajarannya, 13(1), 66-72. https://doi.org/10.26858/retorika.v13i1.11504.

Wahyuni, T. (2020). Kritik dalam ungkapan bahasa Jawa: Kajian semantik kognitif (Criticism in Javanese Idioms: Cognitive Semantic Analysis). Jalabahasa, 16(1), 97-113. https://doi.org/10.36567/jalabahasa. v16i1.453. 